\title{
Behavior patterns of cows with Charolais or Nellore breed predominance fed diets with plant extract or monensin sodium
}

\section{Luciane Rumpel Segabinazzi ${ }^{1}$, Julio Viégas ${ }^{2}$, Leandro da Silva Freitas ${ }^{1}$, Ivan Luiz Brondani², Flânia Mônego Argenta ${ }^{3}$, Juliano Binotto 4}

\author{
1 Programa de Pós-graduação em Zootecnia - Universidade Federal de Santa Maria(UFSM). Address: Avenida Roraima, nº 1000, Bairro Camobi, \\ 97105-900, Santa Maria, RS, Brazil. \\ 2 Departamento de Zootecnia - UFSM. \\ ${ }^{3}$ Curso de Zootecnia - UFSM. \\ ${ }^{4}$ Curso de Medicina Veterinária - UFSM.
}

\begin{abstract}
The objective of this research was to study the ingestive behavior of feedlot cows fed additives based on plant extracts or monensin sodium. Twenty-four Charolais and Nellore crossbred cows with age and average initial weight of 7 years and $423 \mathrm{~kg}$, respectively, were used. The experimental diets were plant extracts: basal diet $+5 \mathrm{~g} / \mathrm{animal} / \mathrm{day}$ of a natural additive composed of $750 \mathrm{mg}$ of essential oil of thyme (Thymus vulgaris), $150 \mathrm{mg}$ of garlic (Allium sativum), $250 \mathrm{mg}$ of rosemary extract (Rosmarimus officinalis), $250 \mathrm{mg}$ of canola oil (Brassica napus), $250 \mathrm{mg}$ extract of quillaja (Quillaja saponaria), and $3350 \mathrm{mg}$ of corn starch; sodium monensin: basal diet $+300 \mathrm{mg} / \mathrm{monensin/animal/day;} \mathrm{and} \mathrm{control:} \mathrm{basal} \mathrm{diet}$ without additive. The basal diet contained sorghum silage and concentrate in a 62:38 ratio. The experimental design was completely randomized with a $3 \times 2$ (3 diets and 2 breed predominances) factorial arrangement, and means were compared using DMS test at $5 \%$ of significance. The type of additive consumed did not alter animal feeding behavior. Cows with Charolais predominance consumed more dry matter (13.78 vs. $12.38 \mathrm{~kg} /$ day) and neutral detergent fiber (7.81 vs. $6.89 \mathrm{~kg} / \mathrm{day})$, ruminated for longer (8.47 vs. $7.82 \mathrm{~h}$ ), spent more time chewing (13.05 vs $12.01 \mathrm{~h})$, had a greater number of chews per minute (58.88 vs 53.21) and a greater number of ruminal bolus (541.43 vs. 464.09 boluses/day); however, cows with Nellore predominance had greater idling time (11.82 vs. 10.74 h).
\end{abstract}

Key Words: chewing, feedlot, growth promoter, idle, rumination

\section{Introduction}

Information on cattle behavior has become an important tool to evaluate animal diets and performance. Such information helps to understand the mechanisms that induce animals to start or finish their meals, so it contributes to efficiently adjusting feed management. Ruminants are extremely competent in adapting to several feeding conditions that vary according to diet, management and environment (Hodgson, 1990). However, changes in animal feeding habits and behavior have also become an important factor for the evaluation of animal performance, since they are able to change the total digestion of nutrients. Digestible dry matter intake is one of the main factors that influence animal performance, whose variation may be up to $90 \%$, according to the ingestion, and up to $40 \%$, depending on the feed digestibility (Mertens, 1994).

Feed additive growth promoters have been extensively used in animal feeding in order to improve the assimilation of nutrients (Russell \& Strobel, 1989). However, recently, consumers have been regarding their use as possibly harmful to humans due to their link with likely residual effects in meat, eggs and milk, leading to the development of bacterial resistance in humans (Menten, 2001). For this reason, the demand for alternative products instead of growth promotion has been indispensable.

The use of plant extracts may be an important alternative to replace the ionophores used in ruminants diet since they have several chemical compounds, such as essential oils, saponin, spicy and bitter substances, mucilage and flavonoids (Fadiño et al., 2008; Hart et al., 2008), which produce digestive changes similar to the changes induced by ionophores traditionally used in ruminants diet. The compounds present in plant extracts act on the rumen fermentation patterns and promote the increase of propionic acid and of rumen undegradable protein ratios, besides reducing the production of methane (Sliwinski, et al., 2002; Burt, 2004; Pen et al., 2007).

Another interesting characteristic of this type of growth promoter is the presence of some aromas from essential oils that act directly on the olfactory cavity and send a signal to the higher brain center, promoting the release of 
hormones to act positively on the sensation of well-being (Broughan, 2002).

Due to the need for further information on the use of plant extracts in cattle diet, as well as the possibility of replacing the usual ionophores, the objective of this study was to evaluate the consequence of plant additive or monensin sodium on the ingestive behavior of feedlot cull cows.

\section{Material and Methods}

The experiment was performed from November, 2006 to January, 2007 at the Laboratório de Bovinocultura de Corte of the Departamento de Zootecnia at the Universidade Federal de Santa Maria, Rio Grande do Sul, Brazil. The geographical coordinates of the place are 29.43' South Latitude and $53^{\circ} 42^{\prime}$ West Longitude, at 90 -m Altitude; the climate of the region is Cfa (humid subtropical) according to Köppen climate classification (Moreno, 1961). Twentyfour cull cows - derived from rotational crossbreeding between Charolais $(\mathrm{CH})$ and Nellore (NE) -, belonging to the following genetic groups $3 /{ }_{4} \mathrm{CH} 1 /{ }_{4} \mathrm{NE} ; 3 /{ }_{4} \mathrm{NE} 1 /{ }_{4} \mathrm{CH}$; $11 /{ }_{16} \mathrm{CH}^{5 / 16} \mathrm{NE}$ and $11 /{ }_{16} \mathrm{NE} 5 /{ }_{16} \mathrm{CH}$ were used. Females were 7 years old and their average initial body weight was $423 \mathrm{~kg}( \pm 36.21 \mathrm{~kg})$. They were housed in individual stalls of $12 \mathrm{~m}^{2}$ each, covered with asbestos-fiber tiles, with paved ground, and with individual feeders and waterers.

The basal diet was calculated according to the NRC (1996), aiming at an average daily weight gain (ADG) of $1.2 \mathrm{~kg} /$ animal and estimated intake of $2.5 \mathrm{~kg}$ of DM/100 kg of live weight (Table 1$)$. The forage:concentrate ratio used was 62:38 (on a dry matter basis) and sorghum silage was used as forage source. The animals were classified by genetic group, weight and body condition and the following treatments were randomly assigned: plant extracts $=$ basal diet $+5 \mathrm{~g} /$ animal/day of a natural additive composed of $750 \mathrm{mg}$ of essential oil of thyme (Thymus vulgaris), $150 \mathrm{mg}$ of garlic (Allium sativum), $250 \mathrm{mg}$ of rosemary extract (Rosmarimus officinalis), $250 \mathrm{mg}$ of canola oil (Brassica napus), $250 \mathrm{mg}$ extract of quillaja (Quillaja saponaria), and $3350 \mathrm{mg}$ of corn starch; sodium monensin = basal diet + 300 mg/monensin/animal/day; and control: basal diet without additive.

During the feedlot period, animals were freely fed twice a day (7:30 AM and 2:00 PM), so that the concentrate and the additive were manually mixtured to the forage in each feeder at feeding time. Every day before the first meal, the leftovers from the previous day were collected and weighted in order to record the daily intake of dry matter and to verify how much feed would be offered the following day, so that leftover was about 5 to $8 \%$ of the voluntary intake. Representative samples of the diet and leftover components were collected at the beginning of the adaptation period and three times a week over the experimental period. The samples were pre-dried in a forced air oven at $55^{\circ} \mathrm{C}$ for 72 hours to determine the partially dry matter, and then they were processed in a Willey mill (1-mm sieve) to be stored and, eventually, analyzed at the laboratory. Contents of dry matter (DM), organic matter (OM), crude protein (CP), ether extract (EE), and ash were determined according to the AOAC (1995). Neutral detergent fiber (NDF) and acid detergent fiber (ADF) were determined by using polyester bag technique according to Komarek (1993). The levels of acid detergent lignin (ADL) were determined according to Robertson \& Van Soest (1981). Neutral detergent insoluble nitrogen (NDIN) and acid detergent insoluble nitrogen

Table 1 - Nutritional composition and proportion of the ingredients of the basal diet (\%DM)

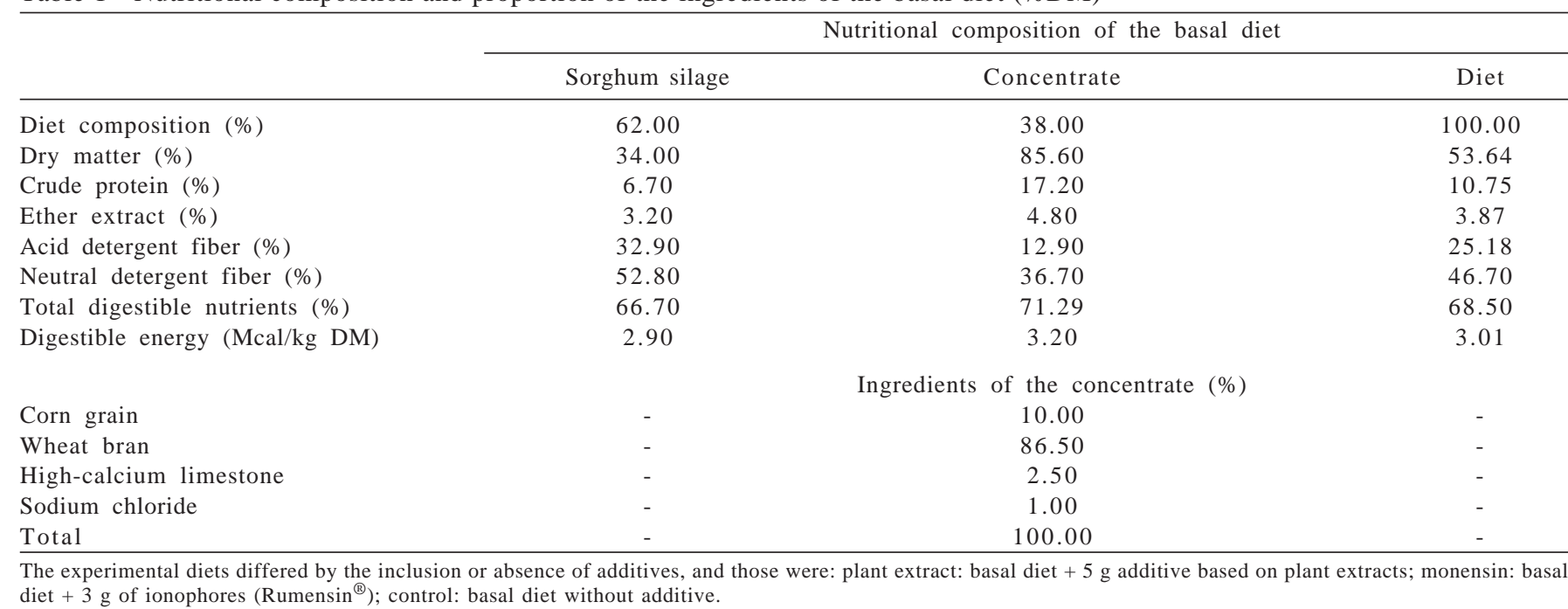


(ADIN) were analyzed according to Licitra et al. (1996). The content of total digestible nutrients (TDN) was calculated in accordance wih Weiss et al. (1992), and the digestible energy (DE) was estimated according to the NRC (1996), in which $1 \mathrm{~kg}$ TDN = 4.4 Mcal DE.

Ingestive behavior data were recorded for six alternate days over the 64 feedlot days. The first day of observation was 25 days after feedlot entry, so that the animals were already adapted to the environment, management, diet, and artificial light at night. During the 24 hours of observation, at every 5 minutes, animals were submitted to one of the following activities: feeding, rumination, idling time or water ingestion. The number of daily meals was recorded after the animals were in the feeder for at least 10 minutes. The behavioral data were interpreted according to the methodology of Polli et al. (1996) and Bürger et al. (2000), where: $\mathrm{RE}_{\mathrm{DM}}=\mathrm{DMI} / \mathrm{TRT} ; \mathrm{RE}_{\mathrm{NDF}}=\mathrm{INDF} / \mathrm{TRT} ; \mathrm{FEDM}=$ $\mathrm{DMI} / \mathrm{FT} ; \mathrm{DCT}=\mathrm{FT}+\mathrm{TRU} ; \mathrm{NCB}=\mathrm{TRT} / \mathrm{TRCB} ; \mathrm{NCM}=$ $(\mathrm{NCRB} * 60) / \mathrm{TRCB} ; \mathrm{RCD}=\mathrm{NCRB} * \mathrm{NCB} ; \mathrm{IT}=\mathrm{TSI}+\mathrm{TLI}$ and TRT = SRT+LRT, where: DMI (g DM/day) is the dry matter intake; INDF (g NDF/day) is the intake of neutral detergent fiber; $\mathrm{RE}_{\mathrm{DM}}(\mathrm{g} \mathrm{DM} / \mathrm{h})$ is the rumination efficiency of $\mathrm{DM}$; $\mathrm{RE}_{\mathrm{NDF}}$ (g NDF/h) is the rumination efficiency of neutral detergent fiber; FEDM is the feeding efficiency of DM; DCT (h/day) is the daily chewing time; FT (h/day) is the feeding time; TRT (h/day) is the total rumination time; NCB (number/ day) is the number of daily chewed boluses; NCM (number/ day) is the number of chews/minutes; NCRB is the number of chews per ruminal bolus; TRCB (sec/bolus) is the time of rumination chews per bolus; RCD (number/day) is the number of rumination chews/day; TLI (h/day) is the time spent lying idle; TSI (h/day) is the time standing idle; SRT ( $\mathrm{h} /$ day) is the standing rumination time; LRT (h/day) is the lying rumination time; and TI (h/day) is the total idle time. Temperature was measured with digital thermometer.

Behavioral data were obtained from the average value recorded in 6 days of visual observation over the experimental period. The experimental design was completely randomized with a $3 \times 2$ factorial arrangement ( 3 diets $\times 2$ breed predominances). Data were submitted to the Shapiro-Wilk normality test and then compared using PROC MIXED procedure with repeated assessments. The compound symmetry covariance structure was the most appropriate for the model. Means were compared using DMS test at $5 \%$ significance and the mathematical pattern used was: $\gamma_{\mathrm{ijk}}=\mu+\tau_{i}+\alpha_{j}+\left(\tau^{*} \alpha\right)_{i j}+\varepsilon_{i j k}$, where: $\gamma_{i j k}=$ dependent variables; $\mu=$ general mean of all observations; $\tau_{i}=$ effect of the $i$-th diet (with plant extracts, monensin or without additive); $\alpha_{j}=$ effect of the $j$-th breed predominance (Charolais or Nellore); $\left(\tau^{*} \alpha\right)_{i j}=$ effect of the interaction between diet and genetic predominance; $\varepsilon_{i j k}=$ residual random error, NID $\left(0, \sigma^{2}\right)$. The analyses were performed using the SAS software (2001).

\section{Results and Discussion}

There was no interaction $(\mathrm{P}>0.05)$ between diet and breed predominance. The type of additive used in the diet did not significantly change $(\mathrm{P}>0.05)$ feed intake, although the average value of feed intake of animals which had consumed the additives based on plant extracts was $16.45 \%$ higher than from control group (Table 2). Fandiño et al. (2008), when working with the inclusion of $500 \mathrm{mg} /$ animal/day of pepper extract in cattle diet, observed an increase of $10.6 \%$ in the intake of dry matter in relation to the ones that did not receive the control diet. According to the literature, the attractive and palatable effect of essential oils and bitter or spicy substances present in some plants may be responsible for increasing dry matter intake since they attract and stimulate taste (Benchaar, 2006b; Cardozo et al., 2006). In another experiment involving the use of plant extracts in the diet of beef cattle, Benchaar et al. (2006a) did not notice difference in dry matter intake and in gain weight when evaluating the performance of calves supplemented with 2 or $4 \mathrm{~g} /$ day of commercial mixture of essential oils consisting of thymol (obtained from thyme), eugenol (obtained from carnation), vanilin (obtained from vanilla), and D-limonene (obtained from citrus fruit), although they noticed that feed efficiency was higher for animals which had consumed $2 \mathrm{~g}$ of the essential oils mixture.

The intake of $300 \mathrm{mg} / \mathrm{animal} / \mathrm{day}$ of monensin did not significantly change $(\mathrm{P}<0.05)$ the intake of dry matter/ animal/day. Research studies show that the use of this type of ionophore may influence cattle feed intake as it causes changes in the ruminal digestibility (Russell \& Strobel, 1989; McCann et al., 1990) and consequently affect dry matter intake. Restle et al. (2001), when evaluating the inclusion of $150 \mathrm{mg} /$ animal/day of sodium monensin in the diet of feedlot cows and heifers noticed that the ones that received monensin had significant reduction $(\mathrm{P}<0.05)$ in dry matter intake with values of 11.51 and $12.55 \mathrm{~kg}$ of DM/day for heifers and cows that consumed monensin versus 11.71 and $13.81 \mathrm{~kg}$ of DM/day for heifers and cows that did not consume monensin in their diet.

The intake of sodium monensin by ruminants, besides contributing to decrease in the incidence of digestive complications due to the intake of high levels of concentrate (Bergen \& Bates, 1984), is also characterized as a strategy to improve animal feed efficiency. This occurs due to changes in the microbial population in the rumen and in the animal 
Table 2 - Means and standard errors of feed intake and rumination efficiency of cull cows according to breed predominance and type of additive consumed

\begin{tabular}{|c|c|c|c|c|}
\hline \multicolumn{4}{|c|}{ Type of additive } & \multirow[b]{2}{*}{ Mean } \\
\hline & Plant extracts & Sodium monensin & Control & \\
\hline \multicolumn{5}{|c|}{ DMI, kg of dry matter intake/day } \\
\hline Nellore & $13.26 \pm 0.94$ & $12.02 \pm 0.94$ & $11.87 \pm 0.94$ & $12.38 b \pm 0.54$ \\
\hline Mean & $13.96 \pm 0.59$ & $12.63 \pm 0.59$ & $12.66 \pm 0.59$ & \\
\hline \multicolumn{5}{|c|}{ DMCLW, $\mathrm{kg}$ of dry matter $/ 100 \mathrm{~kg}$ of live weight } \\
\hline Mean & $2.97 \pm 0.11$ & $2.72 \pm 0.11$ & $2.70 \pm 0.11$ & \\
\hline \multicolumn{5}{|c|}{ NDFC, kg of neutral detergent fiber/day } \\
\hline Charolais & $8.34 \pm 0.40$ & $7.46 \pm 0.40$ & $7.65 \pm 0.40$ & $7.81 \mathrm{a} \pm 0.23$ \\
\hline Nellore & $7.06 \pm 0.52$ & $6.85 \pm 0.52$ & $6.76 \pm 0.52$ & $6.89 \mathrm{~b} \pm 0.30$ \\
\hline Mean & $7.70 \pm 0.33$ & $7.15 \pm 0.33$ & $7.16 \pm 0.33$ & \\
\hline \multicolumn{5}{|c|}{$\mathrm{RE}_{\mathrm{DM}}$, gram of $\mathrm{DM} /$ rumination time } \\
\hline Charolais & $1.664 \pm 90$ & $1.648 \pm 90$ & $1.608 \pm 90$ & $1.640 \pm 90$ \\
\hline Nellore & $1.665 \pm 116$ & $1.567 \pm 116$ & $1.547 \pm 116$ & $1.593 \pm 116$ \\
\hline Mean & $1.664 \pm 73$ & $1.607 \pm 73$ & $1.577 \pm 73$ & \\
\hline \multicolumn{5}{|c|}{$\mathrm{RE}_{\mathrm{NDF}}$, gram of $\mathrm{NDF} /$ rumination time } \\
\hline Charolais & $947 \pm 48$ & $926 \pm 48$ & $915 \pm 48$ & $929 \pm 28$ \\
\hline Nellore & $885 \pm 62$ & $894 \pm 62$ & $881 \pm 62$ & $886 \pm 36$ \\
\hline Mean & $916 \pm 40$ & $910 \pm 40$ & $898 \pm 40$ & \\
\hline
\end{tabular}

Means followed by capital letters in the same row differ $(\mathrm{P}<0.05)$ by the DMS test.

Plant extract $=$ basal diet +5 g additive based on plant extracts; monensin = basal diet +3 g of ionophores (Rumensin $\left.{ }^{\circledR}\right)$; control $=$ basal diet without additive. $\mathrm{DMI}=$ dry matter intake; DMCLW = dry matter intake adjusted to live weight percentage; NDFC = neutral detergent fiber intake; DM = dry matter; FEDM = dry matter consumed per unit of time; $\mathrm{RE}_{\mathrm{DM}}=$ rumination efficiency of dry matter; $\mathrm{RE}_{\mathrm{NDF}}=$ rumination efficiency of neutral detergent fiber; $\mathrm{NDF}=$ neutral detergent fiber.

digestive metabolism, improving the efficiency of energetic and protein metabolism and enhancing animal performance (Russell \& Strobel, 1989). When evaluating the inclusion of $200 \mathrm{mg}$ of sodium monensin/animal/day in the diet of Holstein steers, Fereli et al. (2010) did not see differences $(\mathrm{P}>0.05)$ in dry matter intake, although they noticed an increase of the ruminal and total digestibility of the protein.

Charolais cows were superior in feed intake $(\mathrm{P}<0.05)$ and consumed $11.30 \%$ and $13.35 \%$ more dry matter and neutral detergent fiber, respectively, comparing with Nellore females (Table 2). According to Taylor (1969), changes in animal feed intake from different breeds can be explained by their weight, mainly due to the difference in the degree of maturity and of precocity, since this implies variation in the competition for abdominal space between the gastrointestinal tract, vital organs, adipose and muscle tissue of the carcass. The same was reported by Owens et al. (1993), when stating that the increase in feed intake happens due to differences in animal body composition, so that they show intake directly proportional to protein mass and inversely related to fat deposition. Thus, breeds chosen for high weight gains as Charolais are indirectly chosen for high dry matter intake.
The addition of additives based on plant extracts or monensin in the diet did not change $(\mathrm{P}>0.05)$ the intake of neutral detergent fiber (NDF), and the means were 7.70, $7.15 \mathrm{~kg}$ of NDF/animal/day for the respective additives, and 7.16 NDF/animal/day for control group (Table 2). This result may be a consequence of dry matter intake, and of the nutritional composition of the diets whose only variation was the inclusion or absence of additives (Table 1).

Feed intake adjusted to live weight percentage was also similar $(\mathrm{P}>0.05)$ between the animals, regardless of diet or breed predominance.

The amount of dry matter consumed per unit of time was similar $(\mathrm{P}<0.05)$ between animals, and the average was $3,364,2,751$ and 3,183 grams of dry matter/hour for animals that consumed plant extract, monensin, and control. The essential oils present in some plants such as thyme, garlic and rosemary have a smell that characterize them as possible digestion stimulants (Fadiño et al., 2008; Benchaar et al., 2006b; Cardozo et al., 2006). Thus, this could contribute to increasing dry matter intake or even provide a faster digestion. Another factor that could influence feeding efficiency of dry matter/hour is the palatability of monensin, 
which becomes lower as the animal gets older (Baile et al., 1979; Restle et al., 2001). Thus, smaller palatability would lead to smaller ingestive stimulus, and consequently, animals would ingest more slowly. However, both palatability of diets as breed predominance seem not have been relevant to promote changes $(\mathrm{P}<0.05)$ on the digestion efficiency (Table 2).

The inclusion of feed additive growth promoters in the diet did not change $(\mathrm{P}>0.05)$ rumination efficiency of $\mathrm{DM}$ $\left(R E_{D M}\right)$ and neutral detergent fiber efficiency $\left(R E_{N D F}\right)$ either, where the average values were 1,616 grams of dry matter/hour of rumination and 908 grams of NDF/hour of rumination, respectively. These behavioral characteristics have an important role in the evaluation of the ruminant digestive aspects, since they focus directly on the process of feed particle fractionation, in rumen fermentation action, and in its digestive processes. According to Dulphy et al. (1980), chewing and rumination efficiencies can be reduced in diets with high content of fiber due to the bigger difficulty in decreasing the size of the particles from fibrous materials. Differences in the fiber degradation process were also mentioned by Mendonça et al. (2004) and Freitas et al. (2010), as a determinant factor in rumination efficiency. When evaluating the behavioral response of Holstein cows fed different source of forage, Mendonça et al. (2004) noticed that rumination efficiency of NDF was higher in animals which consumed diet with corn silage (744.96 grams NDF/hour) in comparison with those which consumed sugar cane (595.96 grams NDF/hour). Freitas et al. (2010), when evaluating the replacement of corn silage by sunflower silage, noticed less efficiency in the rumination of NDF as there was an increase in the replacement of corn silage by sunflower silage in diet, although the level of NDF in the diet, as well as the daily intake of dry matter and NDF had been similar between the treatments.

Time spent with feed was not influenced $(\mathrm{P}>0.05)$ by the type of additive or breed predominance (Table 3 ). In accordance with literature, time devoted to feeding does not seem to be related to environmental conditions (Pires et al., 1999), to the forage:concentrate ratio, to the level of fiber in diet (Missio et al., 2010; Bürger et al.,2000; Dulphy et al., 1980) or to the type of forage used (Mendonça et al., 2004; Freitas et al., 2010).

Animals with Charolais breed predominance had greater rumination time (8.3\%) in relation to the Nellore animals (Table 3). This can be attributed to the higher dry matter intake from animals of Charolais breed predominance (Table 2).

There are differences between individuals on what concerns the duration and division of the digestive and rumination activities that seem to be related to animal hunger, to the energy demand supply, to the anatomic differences and ruminal fill (Fischer et al., 1998). Restle et al. (2002), when studying Nellore and Charolais breeds fattening, reported that Nellore animals are more precocious in depositing subcutaneous fat in the carcass, and as this is one of the least fats to be deposited there is usually great accumulation of intermuscular fat and between the inner organs, decreasing the abdominal space that causes the decline in DM intake and thus the reduction in feeding and rumination time.

Table 3 - Means and standard errors of digestive activities of cull cows according to breed predominance and type of additive consumed

\begin{tabular}{|c|c|c|c|c|}
\hline \multirow[b]{2}{*}{ Breed predominance } & \multicolumn{3}{|c|}{ Types of additives } & \multirow[b]{2}{*}{ Mean } \\
\hline & Plant extract & Sodium monensin & Control & \\
\hline \multicolumn{5}{|c|}{ Feeding time, hours } \\
\hline Charolais & $4.66 \pm 0.28$ & $4.95 \pm 0.28$ & $4.12 \pm 0.28$ & $4.57 \pm 0.16$ \\
\hline Nellore & $3.96 \pm 0.36$ & $4.44 \pm 0.36$ & $4.13 \pm 0.36$ & $4.18 \pm 0.21$ \\
\hline Mean & $4.31 \pm 0.23$ & $4.69 \pm 0.23$ & $4.37 \pm 0.23$ & \\
\hline \multicolumn{5}{|c|}{ Rumination time. hours } \\
\hline Charolais & $8.88 \pm 0.26$ & $8.11 \pm 0.26$ & $8.43 \pm 0.26$ & $8.47 a \pm 0.15$ \\
\hline Nellore & $8.01 \pm 0.33$ & $7.75 \pm 0.33$ & $7.72 \pm 0.33$ & $7.82 \mathrm{~b} \pm 0.19$ \\
\hline Mean & $8.44 \pm 0.21$ & $7.93 \pm 0.21$ & $7.52 \pm 0.21$ & \\
\hline \multicolumn{5}{|c|}{ Idle time. hours } \\
\hline Charolais & $10.33 \pm 0.43$ & $10.59 \pm 0.43$ & $11.32 \pm 0.43$ & $10.74 b \pm 0.25$ \\
\hline Nellore & $11.90 \pm 0.55$ & $11.63 \pm 0.55$ & $11.95 \pm 0.55$ & $11.82 \mathrm{a} \pm 0.32$ \\
\hline Mean & $11.15 \pm 0.35$ & $11.11 \pm 0.35$ & $11.63 \pm 0.35$ & \\
\hline \multicolumn{5}{|c|}{ Water ingestion time. hours } \\
\hline Charolais & $0.12 \pm 0.002$ & $0.13 \pm 0.002$ & $0.12 \pm 0.002$ & $0.12 \pm 0.001$ \\
\hline Nellore & $0.12 \pm 0.002$ & $0.12 \pm 0.002$ & $0.12 \pm 0.002$ & $0.12 \pm 0.001$ \\
\hline Mean & $0.12 \pm 0.001$ & $0.12 \pm 0.001$ & $0.12 \pm 0.001$ & \\
\hline
\end{tabular}

Means followd by capital letters in the same row differ $(\mathrm{P}<0.05)$ by the DMS test.

Plant extract $=$ basal diet $+5 \mathrm{~g}$ additive based on plant extracts; monensin $=$ basal diet $+3 \mathrm{~g}$ of ionophores $\left(\right.$ Rumensin $\left.{ }^{\circledR}\right)$; control $=$ basal diet without additive. 
Van Soest et al. (1991) and Polli et al. (1996) reported that rumination activity is highly influenced by the quality and quantity of feed ingested, since it happens right after feeding, when the animal is full and calm. Factors related to diet, such as the level and the type of fiber, may influence directly the ruminal parameters. This was verified by Pereira et al. (2007), when evaluating the ingestive behavior of dairy heifers consuming diets with 30 or $60 \%$ of NDF, observed that the feeding and rumination times increased from $3.53 \mathrm{~h}$ and $7.23 \mathrm{~h}$ to $4.9 \mathrm{~h}$ and $8.59 \mathrm{~h}$ respectively due to the increase in the level of NDF in diet. Freitas et al. (2010) reported that the replacement of corn silage by sunflower silage allows an increase in the time spent in rumination even with very similar levels of NDF, confirming that the digestive characteristics of the fiber can be considered a determining factor to change rumination time.

Idle time differed $(\mathrm{P}<0.05)$ due to breed predominance, and the animals with Nellore breed predominance spent $10.05 \%$ more time in this activity in comparison with animals with Charolais breed predominance (Table 3). This confirms the information reported by Polli et al. (1995) that indicates that the time spent standing idle is inversely related to the increase of feeding and rumination. Idle time was not influenced by additives intake and this confirms the results reported by Silva et al. (2005), who stated that this activity tends to increase as the content of NDF decreases in diet, since the intake of neutral detergent fiber did not interfere in the diets (Table 2). Water ingestion was not influenced ( $\mathrm{P}>0.05$ ) by experimental diets or by breed predominance. The similarity in the nutritional profile of the evaluated diets may have contributed to this result (Table 1). According to the NRC (2001), water intake can be altered by factors related to the content of dry matter consumed, the nutritional composition of the diet, the environmental temperature and the animal production level.

In relation to the time the cows stayed more in the feeders, three peaks of feeding (Figure 1) were observed. The first and the second coincided with the time of feed supply; those were at 07:30 AM and 02:00 PM. These results emphasize the assumption that the animals are conditioned to go for the feed at the time it is offered (Jaster

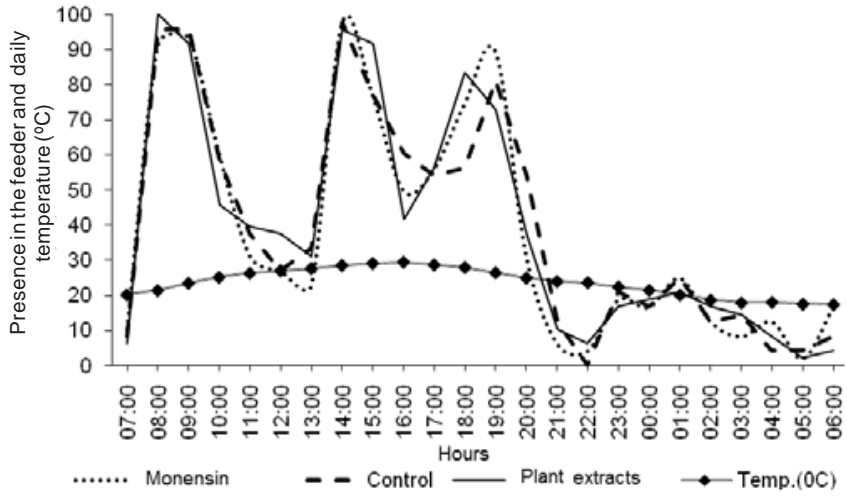

Figure 1 - Presence of animals in the feeders (\%) and temperature $\left({ }^{\circ} \mathrm{C}\right)$ in the nycthemeral period.

\& Murphy, 1983). According to the literature, the probability of the animal being or staying in its feeding activity reaches its maximum value immediately after feed is offered, since it is fresh (Damasceno et al., 1999 Miranda et al., 1999).

The third feeding peak was recorded between 6:00 PM and 8:00 PM, time when temperature tends to go down. This result confirms some research studies that state that in case of higher temperatures, cattle tend to reduce feeding frequency during the hottest hours of the day, intensifying the activity in the first hours in the morning and at the end of the afternoon (Ray \& Roubicek, 1971; Blackshaw \& Blackshaw, 1994). Minimum and maximum temperatures recorded were 29.5 and $17.4^{\circ} \mathrm{C}$ respectively, resulting in a daily average of $23.4^{\circ} \mathrm{C}$.

Breed predominance, as well as the attractive and stimulant effect of the plant extracts mentioned by Benchaar et al. (2006b) and Cardozo et al. (2006) or the low palatability shown by monensin did not show significant changes $(\mathrm{P}>0.05)$ in the number of meals and the time destined to them (Table 4). (Baile et al., 1979; Restle et al., 2001). According to Bürger et al. (2000), time destined to meals seem to be more related to the level of concentrate in the diet. Time spent eating meals decreases linearly with the increase of the levels of concentrate in the diet and it may be associated with the rate of passage of fiber and the smallest time of its retention in the ruminal compartments

Table 4 - Means and probabilities for the number of daily meals (NDM) and the time destined to meals (TM) performed by cull cows according to breed predominance and the type of additive consumed

\begin{tabular}{|c|c|c|c|c|c|c|c|}
\hline & & Type of additive & & & Breed & inance & \\
\hline & Plant extracts & Sodium monensin & Control & $\mathrm{P}$ & Charolais & Nellore & $\mathrm{P}$ \\
\hline NDM & 8.34 & 9.12 & 8.88 & 0.4238 & 8.61 & 8.96 & 0.4765 \\
\hline TM, min. & 31.71 & 30.60 & 28.51 & 0.5231 & 32.42 & 28.13 & 0.0777 \\
\hline
\end{tabular}

Plant extract $=$ basal diet +5 g additive based on plant extracts; monensin $=$ basal diet +3 g of ionophores (Rumensin ${ }^{\circledR}$ ); control $=$ basal diet without additive. 
(Dado \& Allen, 1995). Greater rates of passage of fiber can be reached as the rumination efficiency of dry matter efficiency and rumination efficiency of neutral detergent fiber increase (Freitas et al., 2010). Miranda et al. (1999), when evaluating the ingestive behavior of Holstein-Zebu heifers in diets based on sugar cane with a forage:concentrate ratio of 82:18 and 88:12 noticed that the replacement of urea by probiotics did not show difference $(\mathrm{P}>0.05)$ in the number and time of meals/day, and the means were 11.62 and 28.70 minutes, respectively.

Breed was the only factor that had influence $(\mathrm{P}<0.05)$ on the daily time spent with chewing activities, and the values were 13.05 and 12.02 hours for animals with Charolais and Nellore breed predominance, respectively (Table 5). This result reflects the greatest time used for rumination shown by Charolais (Table 4).

Recently, daily chewing time has been one of the most studied and used measures to evaluate the effectiveness of the fiber, since chewing stimulates saliva production, maceration of feed, ruminal $\mathrm{pH}$, percentage of milk fat, and dry matter intake (Colenbrander et al. 1991). Furthermore, the number of chews/minute and the number of daily rumination chews were lower $(\mathrm{P}<0.05)$ for animals from the Zebu breed, and the respective values were 10.65 and $19.61 \%$ lower in relation to the animals from the European breeding group. In this case, more rumination chews may be related to the greater number of ruminal boluses a day, since the number and the time of chews per ruminal bolus were similar $(\mathrm{P}>0.05)$. The increase in dry matter intake at the same feeding time may increase the rumination time and the daily rumination chews, because they result in less maceration and milling efficiency at the digestion time.

Feed additive growth promoters used in the diets did not show changes $(\mathrm{P}<0.05)$ in the chewing activities or in the number of daily ruminal boluses. This result confirms the ones reported by Miranda et al. (1999), who observed that the addition of probiotics such as yeast did not influence these activities. Some studies report that the time of chews per ruminal bolus can be reduced as the animals increase the efficiency in the reduction of the size of particles per unit of time by reducing time interval between the ruminal boluses or by increasing the rate of mandibular movements/ hour (Bae et al., 1981; Deswysen et al., 1987).

Table 5 - Means and standard errors for digestive activities of cull cows according to breed predominance and the type of additive consumed

\begin{tabular}{|c|c|c|c|c|}
\hline \multirow[b]{2}{*}{ Breed predominance } & \multicolumn{3}{|c|}{ Type of additive } & \multirow[b]{2}{*}{ Mean } \\
\hline & Plant extracts & Sodium monensin & Control & \\
\hline \multicolumn{5}{|c|}{ Daily chewing time, hour } \\
\hline Charolais & $13.55 \pm 0.41$ & $13.06 \pm 0.41$ & $12.54 \pm 0.41$ & $13.05 a \pm 0.24$ \\
\hline Nellore & $11.98 \pm 0.53$ & $12.19 \pm 0.53$ & $11.86 \pm 0.53$ & $12.01 \mathrm{~b} \pm 0.30$ \\
\hline Mean & $12.76 \pm 0.34$ & $12.62 \pm 0.34$ & $12.20 \pm 0.34$ & \\
\hline \multicolumn{5}{|c|}{ Number of chews/minute } \\
\hline Charolais & $57.41 \pm 1.74$ & $58.17 \pm 1.74$ & $61.05 \pm 1.74$ & $58.88 \mathrm{a} \pm 1.00$ \\
\hline Nellore & $56.28 \pm 2.24$ & $51.09 \pm 2.24$ & $52.26 \pm 2.24$ & $53.21 \mathrm{~b} \pm 1.2 \mathrm{~g}$ \\
\hline Mean & $56.84 \pm 1.42$ & $54.63 \pm 1.42$ & $56.65 \pm 1.42$ & \\
\hline \multicolumn{5}{|c|}{ Number of daily rumination chews } \\
\hline Charolais & $30.591 \pm 1.330$ & $28.263 \pm 1.330$ & $31.002 \pm 1.330$ & $29.952 \mathrm{a} \pm 768$ \\
\hline Nellore & $27.033 \pm 1.717$ & $23.788 \pm 1.717$ & $24.301 \pm 1.717$ & $25.041 b \pm 991$ \\
\hline Mean & $28.812 \pm 1.086$ & $26.025 \pm 1.086$ & $27.651 \pm 1.086$ & \\
\hline \multicolumn{5}{|c|}{ Number of ruminal bolus/day } \\
\hline Charolais & $559.10 \pm 27.84$ & $509.27 \pm 27.84$ & $555.93 \pm 27.84$ & $541.43 \mathrm{a} \pm 16.08$ \\
\hline Nellore & $446.38 \pm 35.95$ & $477.89 \pm 35.95$ & $468.00 \pm 35.95$ & $464.09 \mathrm{~b} \pm 20.75$ \\
\hline Mean & $502.74 \pm 22.73$ & $493.58 \pm 22.73$ & $511.96 \pm 22.73$ & \\
\hline \multicolumn{5}{|c|}{ Number of chews/ruminal bolus } \\
\hline Charolais & $54.93 \pm 2.59$ & $55.72 \pm 2.59$ & $56.27 \pm 2.59$ & $55.64 \pm 1.50$ \\
\hline Nellore & $61.56 \pm 3.35$ & $50.12 \pm 3.35$ & $51.79 \pm 3.35$ & $54.49 \pm 1.93$ \\
\hline Mean & $58.24 \pm 2.12$ & $52.95 \pm 2.12$ & $54.03 \pm 2.12$ & \\
\hline \multicolumn{5}{|c|}{ Chewing time/ruminal bolus/seconds } \\
\hline Charolais & $57.42 \pm 2.57$ & $57.53 \pm 2.57$ & $55.59 \pm 2.57$ & $56.85 \pm 1.49$ \\
\hline Nellore & $65.88 \pm 3.32$ & $58.72 \pm 3.32$ & $59.41 \pm 3.32$ & $61.34 \pm 1.92$ \\
\hline Mean & $61.65 \pm 2.10$ & $58.12 \pm 2.10$ & $57.5 \pm 2.10$ & \\
\hline
\end{tabular}

Means followed by capital letters in the same row differ $(\mathrm{P}<0.05)$ by the DMS test.

Plant extract $=$ basal diet $+5 \mathrm{~g}$ additive based on plant extracts; monensin $=$ basal diet $+3 \mathrm{~g}$ of ionophores $\left(\right.$ Rumensin $\left.{ }^{\circledR}\right)$; control $=$ basal diet without additive . 


\section{Conclusions}

The intake of additives based on plant extracts and sodium monensin does not change the ingestive behavior of feedlot cull cows. Animals of Charolais breed predominance show higher feed intake and rumination time, besides spending more time chewing and showing a greater number of chews/minute, greater number of rumination chews and a greater number of daily ruminal bolus. However, idle time was longer for cows of Nellore breed predominance.

\section{References}

ASSOCIATION OF OFFICIAL ANALYTICAL CHEMISTRY A.O.A.C. Official methods of analysis. 16.ed. Washington, D.C.: 1995. 2000p.

BAE, D.H.; WELCH, J.; SMITH, A.M. et al. Efficiency of mastication in relation to hay intake by cattle. Journal of Animal Science, v.52, n.6, p.1371-1375, 1981.

BAile, C.A.; McLAUGHLin, C.L.; POTTER, E.L. et al. Feeding behavior changes of cattle during introduction of monensin with roughage or concentrate diets. Journal of Animal Science, v.48, n.6, p.1501-1508, 1979.

BENCHAAR, C.; DUYNISVELD, J.L.; CHARMLEY, E. Effects of monensin and increasing dose levels of a mixture of essential oil compounds on intake, digestion and growth performance of beef cattle. Canadian Journal of Animal Science, v.86, n.1, p.91-96. 2006a.

BENCHAAR. C.; PETIT, H.V.; WHYTE, T. D. et al. Effects of addition of essential oils and monensin premix on digestion, ruminal fermentation, milk production, and milk composition in dairy cows. Journal of Dairy Science, v.89, n.11, p.4352-4364, 2006b.

BERGEN, W.G.; BATES, D.B. Ionophores: their effect on production efficiency and mode of action. Journal of Animal Science, v.58, n.6, p.1465-1483, 1984.

BLACKSHAW, J.K.; BLACKSHAW, A.W. Heat stress in cattle and the effect of shade on production and behaviour: a review. Australian Journal of Experimental Agriculture, v.34, n.2, p.285-295, 1994.

BROUGHAN, C. Odours, emotions, and cognition - how odours may affect cognitive performance. The International Journal of Aromatherapy, v.12, n.2, p.92-98, 2002.

BÜRGER, P.J; PEREIRA, J.C; QUEIROZ, A.C. et al. Comportamento ingestivo em bezerros holandeses alimentados com dietas contendo diferentes níveis de concentrado. Revista Brasileira de Zootecnia, v.29, n.1, p.236-242, 2000.

BURT, S. Essential oils: their antibacterial properties and potential applications in foods - a review. International Journal Food Microbiology, v.94, n.3, p.223-253, 2004.

CARDOZO, P.W.; CALSAMIGLIA, S.; FERRET, A. et al. Effects of alfalfa extract, anise, capsicum, and a mixture of cinnamaldehyde and eugenol on ruminal fermentation and protein degradation in beef heifers fed a high-concentrate diet. Journal of Animal Science, v.84, n.10, p.2801-2808, 2006.

COLENBRANDER, V.F.; NOLLER, C.H.; GRANT, R.J. Effect of fiber content and particle size of alfalfa silage on performance and chewing behavior. Journal of Dairy Science, v.74, n.12, p.2681-2681, 1991.

DADO, R.G.; ALLEN, M.S. Intake limitations, feeding behavior, and rumen function of cows challenged with rumen fill from dietary fiber or inert bulk. Journal of Dairy Science, v.78, n.1, p.118-133, 1995
DAMASCENO, J.C.; BACCARI JÚNIOR, F.; TARGA, L.A. et al. Respostas comportamentais de vacas holandesas com acesso à sombra constante ou limitada. Pesquisa Agropecuária Brasileira, v.34, n.4, p.709-715, 1999.

DESWYSEN, A.G.; ELLIS, W.C.; POND, K.R. et al. Interrelationship among voluntary intake, eating and ruminating behavior and ruminal motility of heifers fed corn silage. Journal of Animal Science, v.64, n.3, p.835-841, 1987.

DULPHY, J.P.; REMOND, B.; THERIEZ, M. Ingestive behavior and related activities in ruminants. In: RUCKEBUSH, Y.; THIVEND, P. (Eds.). Digestive physiology and metabolism in ruminants. Lancaster: MTP, 1980. p.103-122.

FANDIÑO, I.; CALSAMIGLIA, S.; FERRET, A. et al. Anise and capsicum as alternatives to monensin to modify rumen fermentation in beef heifers fed a high concentrate diet. Animal. Feed Science and Technology, v.145, n.4 p.409-417 2008.

FERELI, F.; BRANCO, A.F.; JOBIN, C.C. et al. Monensina sódica e Saccharomyces cerevisiae em dietas para bovinos: fermentação ruminal, digestibilidade dos nutrientes e eficiência de síntese microbiana. Revista Brasileira de Zootecnia, v.39, n.1, p.183-190, 2010.

FISCHER, V.; DESWYSEN, A.G.; AMOUCHE, E.H. et al. Efeitos da pressão de pastejo sobre o padrão nectemeral do comportamento ingestivo de ovinos em pastagem. Revista Brasileira de Zootecnia, v.27, n.1, p.164-170, 1998.

FREITAS, L.S.; SILVA, J.H.S.; SEGABINAZZI, L.R. et al, Substituição da silagem de milho por silagem de girassol na dieta de novilhos em confinamento: comportamento ingestivo. Revista Brasileira de Zootecnia, v.39, n.1, p.225-232, 2010.

HART, H.J.; YANEZ-RUIZ, D.R.; DUVAL, S.M. et al. Plant extracts to manipulate rumen fermentation. Animal Feed Science and Technology, v.147, n.1, p.08-35, 2008.

HODGSON, J. Grazing management: science into practice. Inglaterra: Longman Handbooks in Agriculture, 1990. 203p.

JASTER, E.H.; MURPHY, M.R. Effects of varying particle size of forage on digestion and chewing behavior of dairy heifers. Journal of Dairy Science, v.66, n.6, p.802-810, 1983.

KOMAREK, A.R. A fiber bag procedure for improved efficiency of fiber analyses. Journal of Dairy Science, v.76, p.250, 1993. (Supl. 1).

LICITRA, G.; HERNANDEZ, T.M.; VAN SOEST, P.J. Standartization of procedures for nitrogen fractionation of ruminant feeds. Animal Feed Science Technology, v.57, n.4, p.347-358, 1996.

McCANN, M.A.; CRADDOCH, B.F.; PRESTON, R.L. et al. Digestibility of cotton plant by-product diets for sheep at two levels of intake. Journal of Animal Science, v.68, n.2, p.285- 295, 1990.

MENDONÇA, S.S.; CAMPOS, J.M. S.; VALADARES FILHO, S.C. et al. Comportamento ingestivo de vacas leiteiras alimentadas com dietas à base de cana-de-açúcar ou silagem de milho. Revista Brasileira de Zootecnia, v.33, n.3, p.723-728, 2004.

MENTEN, J.F.M. Aditivos alternativos na produção de aves: probióticos e prebióticos. In: REUNIÃO ANUAL DA SOCIEDADE BRASILEIRA DE ZOOTECNIA, 38., 2001, Piracicaba. Anais... Piracicaba: Sociedade Brasileira de Zootecnia, 2001. p.141-157.

MERTENS, D.R. Regulation of forage intake. In: FAHEY JUNIOR, G.C. (Ed.) Forage quality, evaluation and utilization. Madison: American Society of Agronomy, 1994. p.450-493.

MIRANDA, L.F.; QUEIROZ, A.C.; VALADARES FILHO, S.C. et al. Comportamento ingestivo de novilhas leiteiras alimentadas com dietas à base de cana-de-açúcar. Revista Brasileira de Zootecnia, v.28, n.3, p.640-620, 1999.

MISSIO R.L.; BRONDANI, I.L.; ALVES FILHO, D.C. et al. Comportamento ingestivo de tourinhos terminados em confinamento, alimentados com diferentes níveis de concentrado na dieta. Revista Brasileira de Zootecnia, v.39, n.7, p.1571-1578, 2010. 
MOREnO, J.A. Clima do Rio Grande do Sul. Porto Alegre: Secretaria da Agricultura, 1961. 41p.

NATIONAL RESEARCH COUNCIL - NRC - Nutrient requirements of beef cattle. 7.ed. Washington, D.C., 1996. 232p.

NATIONAL REQUIREMENT COUNCIL - NRC. Nutrient requirements of beef cattle. 7.ed. Washington, D.C.: National Academy Press, 2001. 242p.

OWENS, F.N.; DUBESKI, P.; HANSON, C.F. Factors that alter the growth and development of ruminants. Journal of Animal Science, v.71, n.11, p.3138-3150, 1993.

PEN, B.; TAKAURA, K.; YAMAGUCHI, S. et al. Effects of Yucca schidigera and Quillaja saponaria with or without $\beta$ 1-4 galactooligosaccharides on ruminal fermentation, methane production and nitrogen utilization in sheep. Animal Feed Science and Technology, v.138, n.1, p.75-88, 2007.

PEREIRA, J.C.; CUNHA, D.N.F.V.; CECON, P.R. et al. Comportamento ingestivo e taxa de passagem de partículas em novilhas leiteiras de diferentes grupos genéticos submetidas a dietas com diferentes níveis de fibra. Revista Brasileira de Zootecnia, v.36, n.6, p.2134-2142, 2007.

PIRES, M.F.A.; VERNEQUE, R.S.; FERREIRA, A.M. et al. Comportamento de vacas holandesas confinadas em free stall, durante o verão e o inverno. In: REUNIÃO ANUAL DA SOCIEDADE BRASILEIRA DE ZOOTECNIA, 36., 1999, Porto Alegre. Anais... São Paulo: SBZ/Gmosis, 1999. (CD-ROM).

POLLI, V.A.; RESTLE, J.; SENNA, D.B. et al. Aspectos relativos à ruminação de bovinos e bubalinos em regime de confinamento. Revista Brasileira de Zootecnia, v.25, n.5, p.987-993, 1996.

POLli, V. A.; RESTlE, J.; SENNA, D.B. Comportamento de bovinos e bubalinos em regime de confinamento. I. Atividades. Ciência Rural, v.25, n.1, p.127-131, 1995.

RAY, D.E.; ROUBICEK, C.B. Behavior of feedlot cattle during two seasons. Journal of Animal Science, v.33, n.1, p.72-76, 1971.

RESTLE, J.; PASCOAL, L.L.; FATURI, C. et al. Efeito do grupo genético e da heterose nas características quantitativas da carcaça de vacas de descarte terminadas em confinamento. Revista Brasileira de Zootecnia, v.31, n.1, p.350-362, 2002 (supl.).

RESTLE, J.; NEUMANN, M.; ALVES FILHO, D.C. et al. Terminação de confinamento de vacas e novilhas sob dietas com ou sem monensina sódica. Revista Brasileira de Zootecnia, v.30, n.6, p.1801-1812, 2001.

ROBERTSON, J.B.; VAN SOEST, P.J. The detergent system of analysis. In: JAMES, W.P.T.; THEANDER, O. (Eds.) The analysis of dietary fibre in food. New York: Marcel Dekker, 1981. p.123-158.

RUSSELL, J.B.; STROBEL, H.J. The effect of ionophores on rumen fermentation. Applied and Environmental Microbiology, v.55, n.1, p.1-6, 1989.

SILVA, R.R.; SILVA, F.F.; CARVALHO, G.G.P. et al. Avaliação do comportamento ingestivo de novilhas $3 / 4$ holandês $\mathrm{x}$ zebu alimentadas com silagem de capim-elefante acrescida de $10 \%$ de farelo de mandioca. Ciência Animal Brasileira, v.6, n.4, p.134-141, 2005.

SLIWINSKI, B.J.; SOLIVA, C.R.; MACHMULLER, A. et al. Efficacy of plant extracts rich in secondary constituents to modify rumen fermentation. Animal Feed Science and Technology, v.101, n.1, p.101-114, 2002.

STATISTICAL ANALYSES SYSTEM - SAS. SAS Language reference. Version 6. Cary: SAS Institute, 2001. 1042p.

TAYLOR, J.C. A relationship between weight of internal fat, fill and herbage intake of grazing cattle. [s.n.]. Nature (London), 1969. p.184-202.

VAN SOEST, P.J.; ROBERTTSON, J.B.; LEWIS, B.A. Methods for dietary fiber neutral detergent fiber, and nonstarch polysaccharides in relation to animal nutrition. Journal of Dairy Science, v.74, n.10, p.3583-3597, 1991.

WEISS, W.P.; CONRAD, H.R.; ST. PIERRE, N.R. A theoreticallybased model for predicting total digestible nutrient values of forages and concentrates. Animal Feed Science and Technology, v.39, n.1, p.95-110, 1992. 